\title{
The quest for pluripotency: a comparative analysis across mammalian species
}

\author{
A S Devika ${ }^{1, *}$, Wasco Wruck ${ }^{2, *}$, James Adjaye ${ }^{2}$ and Smita Sudheer ${ }^{1}$ \\ ${ }^{1}$ Department of Genomic Science, Central University of Kerala, Kerala, India and ${ }^{2}$ Institute for Stem Cell Research \\ and Regenerative Medicine, Medical Faculty, Heinrich Heine University, Düsseldorf, Germany
}

Correspondence should be addressed to J Adjaye: James.Adjaye@med.uni-duesseldorf.de or to S Sudheer: smitasudheer@ cukerala.ac.inl

*(A S Devika and W Wruck contributed equally to this work)

\begin{abstract}
Pluripotency is the developmental potential of a cell to give rise to all the cells in the three embryonic germ layers, including germline cells. Pluripotent stem cells (PSCs) can be embryonic, germ cell or somatic cell in origin and can adopt alternative states of pluripotency: naïve or primed. Although several reports have described the differentiation of PSCs to extra-embryonic lineages, such as primitive endoderm and trophectoderm, this is still debated among scientists in the field. In this review, we integrate the recent findings on pluripotency among mammals, alternative states of pluripotency, signalling pathways associated with maintaining pluripotency and the nature of PSCs derived from various mammals. PSCs from humans and mouse have been the most extensively studied. In other mammalian species, more research is required for understanding the optimum in vitro conditions required for either achieving pluripotency or preservation of distinct pluripotent states. A comparative high-throughput analysis of PSCs of genes expressed in naïve or primed states of humans, nonhuman primates (NHP) and rodents, based on publicly available datasets revealed the probable prominence of seven signalling pathways common among these species, irrespective of the states of pluripotency. We conclude by highlighting some of the unresolved questions and future directions of research on pluripotency in mammals.

Reproduction (2019) 158 R97-R111
\end{abstract}

\section{Introduction}

The zygote is a single cell, endowed with the amazing potency to develop into an entire organism that harbours extreme complexity (reviewed in Leung \& ZernickaGoetz 2015). The most important aspect is the cell fate decisions during its development to form an embryo. In terms of development, pluripotency is a transitory state exhibited by specialised cells in the blastocyst, for a very short period of time, possessing the ability to differentiate into all the cells within the three embryonic germ layers, including the germline cells (Adjaye et al. 2005; reviewed in Weinberger et al. 2016). PSCs can be derived from the pre-implantation (embryonic stem cells (ESCs)), post-implantation embryos (epiblast stem cells (EpiSCs)), primordial germ cells (PGCs) (embryonic germ cells (EGCs)) or somatic cells (somatic cell nuclear transfer (SCNT)-derived ESCs, induced PSCs (iPSCs)). Embryonic germ cells (EGCs) share similar properties with ESCs; however, they sometimes exhibit imprint erasure (reviewed in Leitch \& Smith 2013).

Under in vitro conditions, pluripotent stem cells (PSCs) can beget all the cell types of embryonic and extra-embryonic lineages (reviewed in Beddington \&
Robertson 1989, Xu et al. 2002, Pera et al. 2004, Das et al. 2007, Niakan et al. 2010, Sudheer et al. 2012, Leitch \& Smith 2013, Morgani et al. 2013, Roberts et al. 2014, Kojima et al. 2017). The potency of PSCs in giving rise to cells of the extra-embryonic lineage was first reported in mice, this was based on the presence of colonisation pattern of ESCs in trophectoderm (TE) of chimeras (Beddington \& Robertson 1989). Later on, the competency of hPSCs to differentiate into extraembryonic cells, such as trophoblast and primitive endoderm when exposed to BMP4 was described (Xu et al. 2002, Pera et al. 2004, Das et al. 2007, Sudheer et al. 2012, Horii et al. 2016, Kojima et al. 2017). In spite of several publications from different groups on the differentiation ability of human PSCs to extra-embryonic lineages, these protocols and concept are still debated among scientists in the field (Roberts et al. 2014). Our understanding of pluripotency is on a surge, as several coordinated molecular events underlying pluripotency and differentiation are being discovered, such as the role of signalling pathways, transcription factors, epigenetic factors (DNA and histone modification) and non-coding RNAs (Davidson et al. 2002, Babaie et al. 2007, Brons 
et al. 2007, Tesar et al. 2007, Thomson et al. 2011, Sudheer et al. 2012, Guo et al. 2017; reviewed in Li et al. 2017).

It has been more than three decades since the description of the derivation of mouse PSCs and now, we are capable of reprogramming somatic cells into induced pluripotent stem cells (iPSCs) (Evans \& Kaufman 1981, Thomson et al. 1998, Takahashi \& Yamanaka 2006, 2007, Yu et al. 2007). The nature and state of PSCs may change with respect to the donor organism, the developmental stage, the cell of origin (embryonic, germ or somatic) and the culture conditions (Kerr et al. 2006, Dejosez \& Zwaka 2012, Martello \& Smith
2014; reviewed in Weinberger et al. 2016). Different cell culture conditions can influence the state of the derived PSCs, which can also lead to failure in capturing the developmental state, from which the cells were originally derived.

According to the specific developmental stage of the early embryo or the in vitro culture conditions, PSCs can exist in at least two distinct states - naïve (ground) or primed, which differ in both morphology and molecular characteristics (Fig. 1 and Tables 1,2) (Greber et al. 2007b, Ying et al. 2008, Nichols \& Smith 2009, Sudheer et al. 2016). Naïve pluripotency is the earliest state of pluripotency (ground state), closely resembling

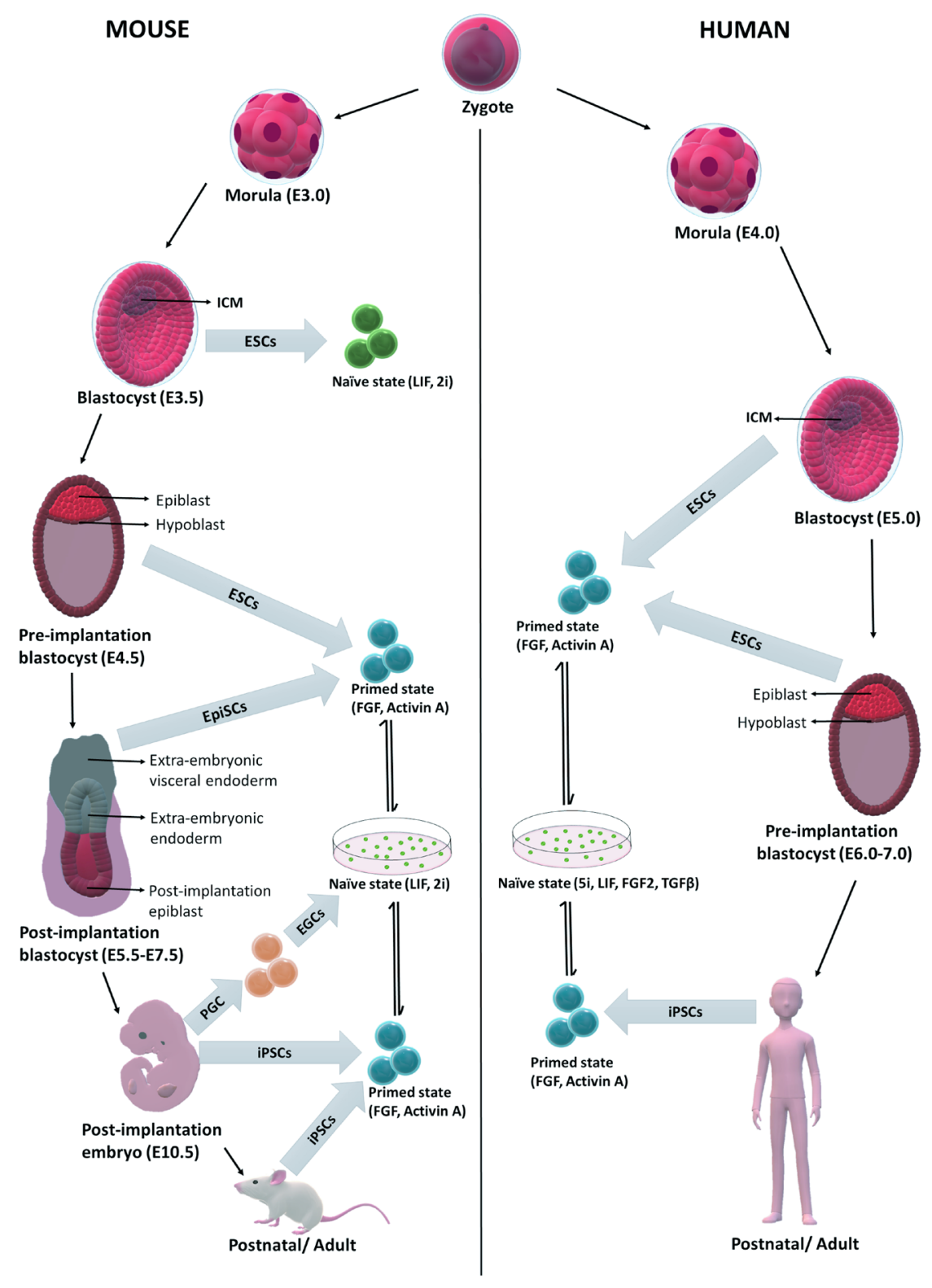

Figure 1 Embryonic pluripotency in mouse and humans. 
Table 1 Comparative features of naïve and primed states of pluripotency.

\begin{tabular}{lll}
\hline & \multicolumn{2}{c}{ Features } \\
\cline { 2 - 3 } & Naïve state of pluripotency & Primed state of pluripotency \\
\hline Donor cells & ICM of pre-implantation blastocyst & Epiblast cells of post-implantation blastocyst \\
Gene expression profiling & Oct4, Nanog, Sox2, KIfs, Esrrb, Tbx3, Tf $c$ 2/1, Gbx2 & Oct4, Sox2, Fgf5, Pou3f1, Meis1, Sox11 \\
Chimera-forming ability & Yes & No \\
Cellular respiration profile & Oxidative phosphorylation, glycolysis & Glycolysis \\
X-chromosome status & XaXa & XaXi \\
Global DNA methylation & Hypomethylation & Hypermethylation \\
Response to 2i & Self-renewal & Differentiation \\
Response to LIF/Stat3 & Self-renewal & None \\
Response to Fgf/Erk & Differentiation & Self-renewal \\
OCT4 enhancer utilisation & Distal & Proximal \\
\hline
\end{tabular}

embryonic epiblast in the pre-implantation blastocyst, in which the cells possess an unbiased ability to form all the embryonic lineages, including germline cells and are capable of giving rise to germline chimeras. On the other hand, primed pluripotency, closely resembling in vivo immediate post-implantation epiblast, is a later state of pluripotency, in which the cells are primed towards lineages ectoderm, mesoderm and endoderm (the three germ layers) and lack germline chimeraforming capability. The two states differ in various characteristics, including gene expression, cellular respiration or metabolism, X-chromosome status, DNA methylation, OCT4 enhancer utilisation and germline chimera formation capability (Fig. 1 and Tables 1, 2) (Ying et al. 2008, Nichols \& Smith 2009; reviewed in Sudheer et al. 2016, Weinberger et al. 2016). Soon after the discovery of the two states, scientists showed that PSCs are interchangeable between the primed and naïve states, by using specific culture conditions and over-expression of the pluripotency factors via transgene expression (Babaie et al. 2007, Bao et al. 2009, Guo et al. 2009, Hanna et al. 2009).

In this review, we discuss the nature of PSCs, the states of pluripotency and the comparative analysis between PSCs of humans, NHP and rodents. In this regard, we performed a comparative analysis of three transcriptome datasets, one from each species (Human (GSE75868); Theunissen et al. 2016), crab-eating macaque (Macaca fascicularis (GSE69708); Chen et al. 2015) and mouse (GSE99494) (Bao et al. 2018), to identify common signalling pathways, irrespective of species differences. To obtain comparable numbers of expressed genes in human and mouse (Affymetrix data), detection $P$ value $<0.001$ was used as gene expression threshold. For nextgeneration sequencing (NGS) data from the monkey, a gene expression threshold of FPKM $>1$ was considered. The analysis revealed both similarities and differences in terms of gene expression and led to the identification of seven signalling pathways presumably active in PSCs of all three species. Although these pathways are known to have important roles in maintaining pluripotency, this analysis provides clues to the evolutionary conservation of their roles as gatekeepers of pluripotency and thus warrants attention.

\section{Pluripotency and its states}

During development, the totipotent zygote gradually loses its flexibility and transforms into an embryo. The polarisation in a developing embryo begins from the eight-cell stage blastomeres (in case of mouse), continues in the morula stage and ends in the first differentiation and lineage segregation, of the inner cell mass (ICM) and trophectoderm (TE) in the blastocyst stage (Kelly 1977; reviewed in Nichols \& Smith 2012; reviewed in De Paepe et al. 2014, Wu \& Schöler 2016). Expression of pluripotency-associated genes - Oct4 and Nanog - in the ICM continues only up to somitogenes in vivo and in contrast, pluripotency can be maintained indefinitely in vitro, thus enabling the manipulation and directed differentiation of PSCs into specific cell lineages found in a developing embryo (Brink et al. 2008, Osorno et al. 2012; reviewed in Smith 2017).

The discovery of self-renewal and the multipotent nature of embryonic carcinoma cells (ECCs) paved the way for a new era of stem cell research (Solter et al. 1970, Stevens 1970). Malignant teratomas contain ECCs, which show overlapping features with PSCs, but are not bona fide PSCs - they are the stem cell component of teratocarcinomas, which are derived from germ cell tumours (GCTs) (Andrews et al. 2005, Greber et al. 2007a, Jung et al. 2010). Earlier studies on ECCs led to the successful isolation and culture of mouse ESCs (mESCs) (Evans \& Kaufman 1981).

ESCs are generally derived from blastocyst and efficient derivation of clonal embryonic stem (ES) cell lines can only be from mid- and late blastocyst stages (Boroviak et al. 2014). However, ESCs have also been successfully derived from various pre-implantation stages and from single blastomeres (Delhaise et al. 1996, Tesar 2005, Chung et al. 2006, Wakayama et al. 2007), resulting in ESCs with similar characteristics (reviewed in Nichols \& Smith 2012). Other than the PSCs derived from embryos, they can also be derived from somatic cells through somatic cell nuclear transfer (SCNT-derived ESCs) or artificial reprogramming (induced pluripotent stem cells - iPSCs) (Takahashi \& Yamanaka 2006, Tachibana et al. 2013). The EGCs derived from PGCs are similar to ESCs and are considered as naïve PSCs, but bona fide EGCs 


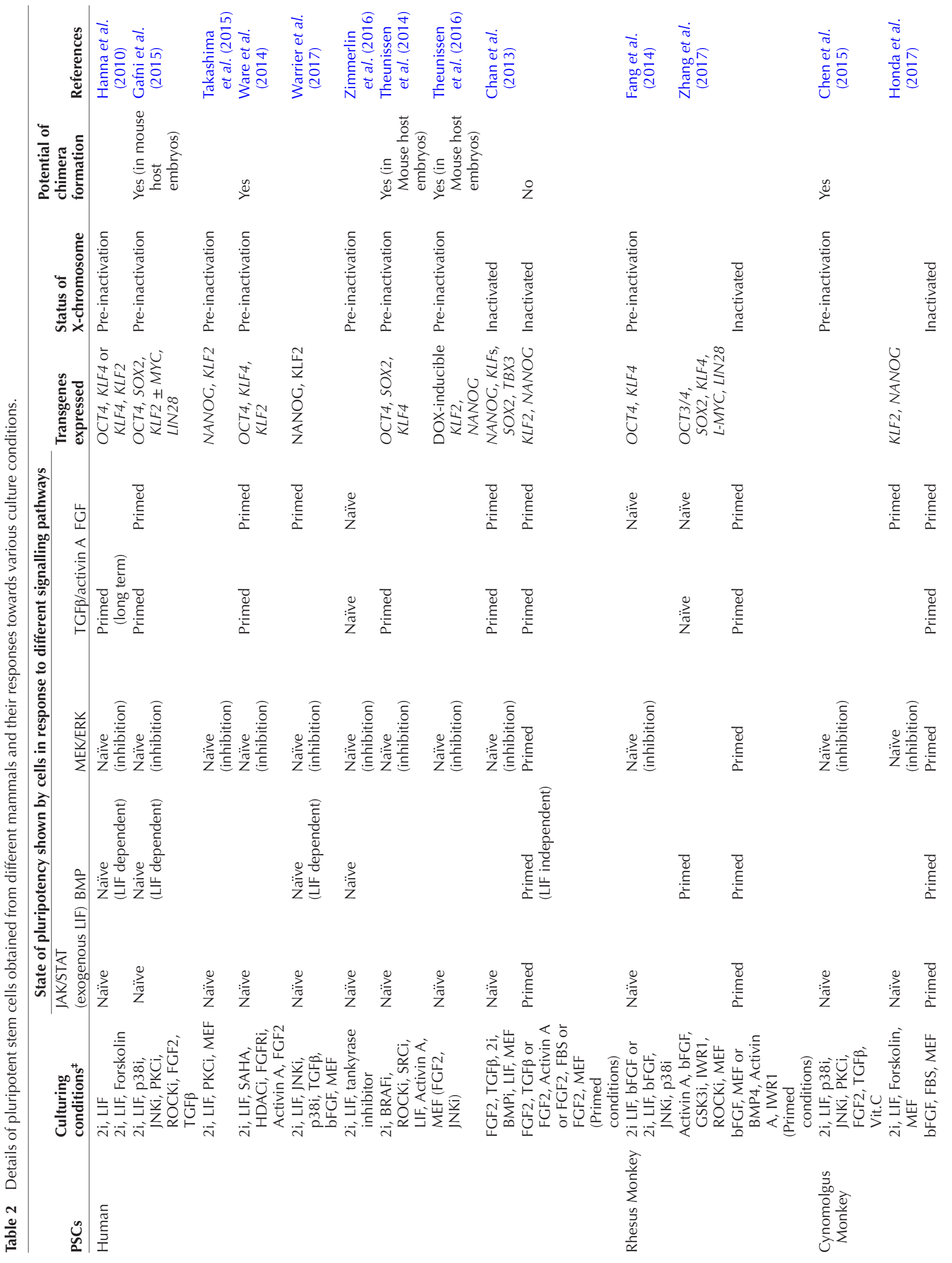




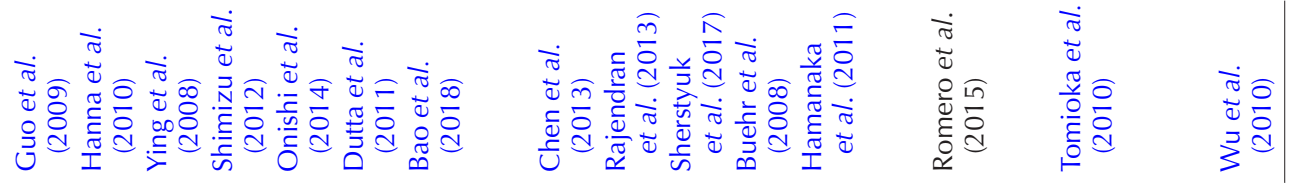

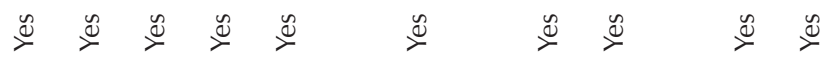

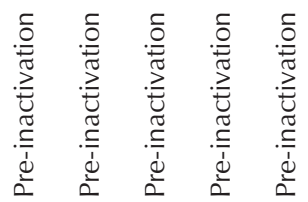
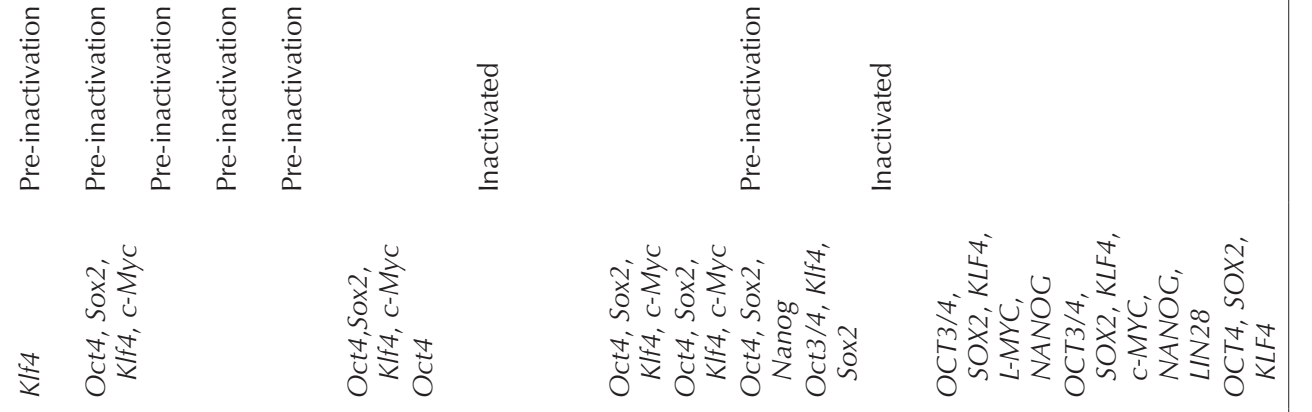

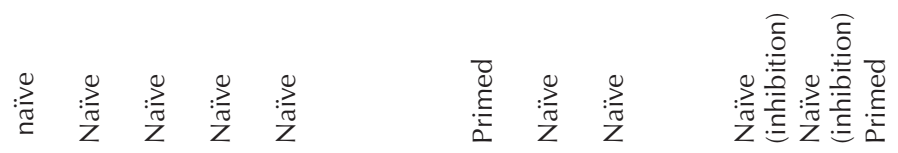

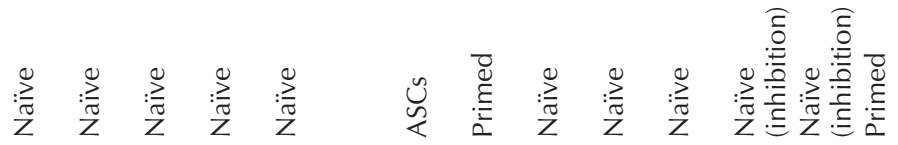

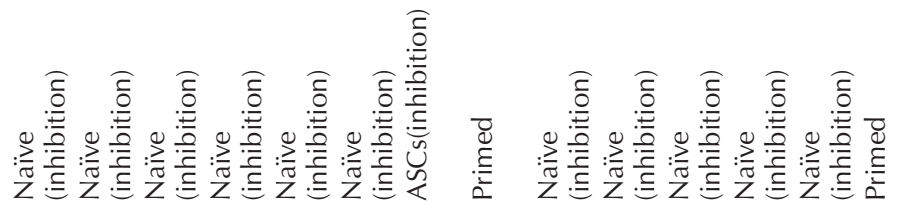

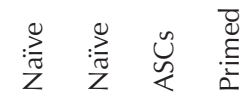

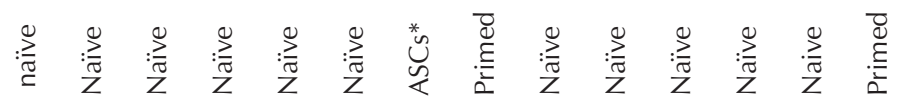

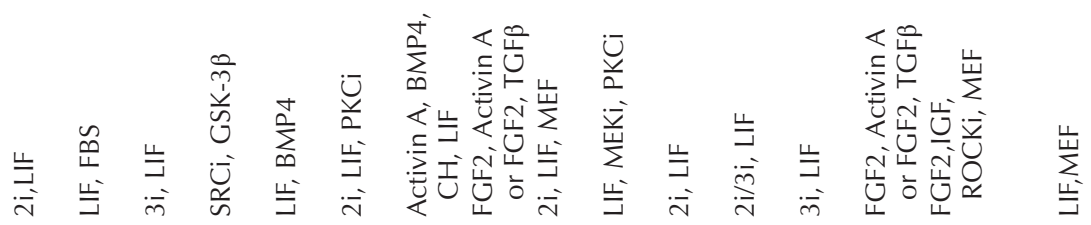

$\frac{9}{2}$

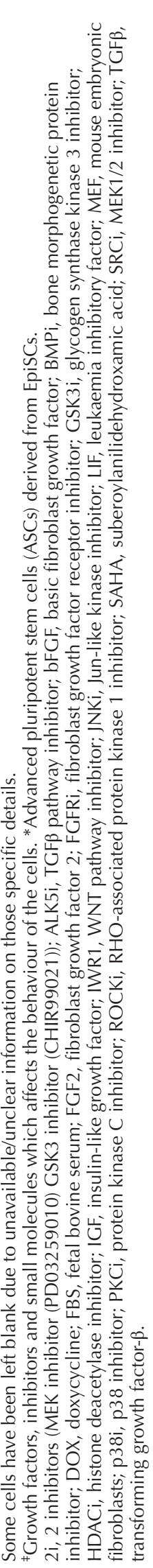

Reproduction (2019) 158 R97-R111 
having naïve pluripotency have been derived only from rat and mouse till now (Matsui et al. 1992, Resnick et al. 1992, Shamblott et al. 1998, Mueller et al. 1999, Leitch et al. 2010; reviewed in Nikolic et al. 2016).

Mouse PSCs of embryonic origin can be derived from pre-implantation blastocyst (E3.5 (3.5-day post coitum)), termed ESCs and post-implantation blastocyst (E5.5-E7.5), termed EpiSCs (Evans \& Kaufman 1981, Martin 1981, Thomson et al. 1998, Brons et al. 2007, Tesar et al. 2007). Pre-implantation ESCs are in a naïve state of pluripotency, possessing germline chimeraforming ability and the post-implantation EpiSCs are in a primed state of pluripotency, and are more restricted, not being able to form germline chimeras (Fig. 1 and Tables 1, 2) (Ying et al. 2008, Nichols \& Smith 2009; reviewed Sudheer et al. 2016, in Weinberger et al. 2016). Naïve PSCs tend to grow as dome-shaped colonies and can be passaged as single cells, thus facilitating clonal propagation. Furthermore, they can give rise to germline chimeras, when introduced into pre-implantation blastocysts (Nichols \& Smith 2009). In contrast, primed PSCs (mEpiSCs and hESCs) form flat colonies but also give rise to germline chimeras (Fig. 1 and Tables 1, 2) (Thomson et al. 1998, Brons et al. 2007, Tesar et al. 2007). The common characteristics shared between naïve (mESCs) and primed PSCs (mEpiSCs and hESCs) include the properties of pluripotency, teratoma formation and embryoid body formation. Numerous pluripotency-associated genes are expressed in common in these cells, but there are also differences in the expression profiles of several genes such as Klf4, Esrrb, Tbx3, Tfcp2l1, Gbx2, Fgf5, Pou3f1, Meis1 and Sox11 (Table 1) (Nichols \& Smith 2009).

In earlier days, mESCs were considered to be similar to the ICM of the early blastocyst, but more recent studies have shown that ESCs are more similar to the epiblast of a pre-implantation blastocyst than the ICM of an early blastocyst (Boroviak et al. 2014). Mouse ESCs can be maintained on feeder layer using a medium containing leukaemia inhibitory factor (LIF), supplemented with serum (LifS condition), which is the 'conventional' culture condition for the derivation of mESCs (Evans \& Kaufman 1981, Smith et al. 1988, Williams et al. 1988, Niwa et al. 1998, 2009). However, the efficiency of mESC derivation in this condition is higher for permissive strains, such as 129 , but not for non-permissive strains (Kawase et al. 1994, Suzuki et al. 1999). Depending on the efficiency of mESC derivation in LifS condition, mouse strains have been classified as permissive or non-permissive. Mouse ESCs can be maintained under feeder-free conditions in the presence of LIF and two small molecules, that inhibit GSK3 $\beta$ (CHIR99021) and ERK/MAPK signalling (PD0325901) ( $2 \mathrm{i} /$ LIF condition or popularly known as the $2 \mathrm{i}$ Media) (Ying et al. 2008). The $2 \mathrm{i} / \mathrm{LIF}$ condition promotes naïve pluripotency and makes the mESC derivation from non-permissive strains also highly efficient (Ying et al. 2008, Nichols et al. 2009). LIF, a cytokine, which activates Stat3, induces mitochondrial respiration and the activity of several transcription factors (Oct4, Nanog, Sox2) that have a decisive role in the gene regulatory network of naïve pluripotency (Kawase et al. 1994, Suzuki et al. 1999, Ying et al. 2008, Nichols et al. 2009, Carbognin et al. 2016).

In place of $2 \mathrm{i} / \mathrm{LIF}$, which supports naïve pluripotency, when mESCs are continuously exposed to bFGF/ACTIVIN A, they develop to a primed state of pluripotency, which is similar to mEpiSCs derived from post-implantation embryo (Thomson et al. 1998, Brons et al. 2007, Tesar et al. 2007). Mouse EpiSCs can be converted into a naïve state by maintaining them in a $2 \mathrm{i} / \mathrm{LIF}$ condition, along with over-expression of Klf4 (Guo et al. 2009). Hence, the states of pluripotency, naïve and primed, are interconvertible, based on the growth conditions/factors used, in both human and mouse (Table 2, Thomson et al. 1998, Brons et al. 2007, Tesar et al. 2007, Guo et al. 2009, Gafni et al. 2015).

\section{Pluripotency in mammals other than primates and rodents}

So far, other than human and mouse, many studies have concentrated on the derivation of PSCs from mammals such as mink, pig, bovine, rabbit, cat, dog, sheep, goat and horse (Sukoyan et al. 1993, Li et al. 2003, Telugu et al. 2010; reviewed in Ezashi et al. 2016, Ogorevc et al. 2016, Osteil et al. 2016). In most of these cases, ESCs have either not been tested for or do not satisfy all the criteria for pluripotency (Fig. 1, Tables 1, 2 and Supplementary data 1 , see section on supplementary data given at the end of this article). Therefore, the characteristics of the cells derived from these mammals are not completely defined. In contrast to ESCs, iPSCs derived from these animals have been shown to satisfy many of the criteria for pluripotency, except the germline chimera formation ability (Supplementary Table 1).

Mink (a semi aquatic mammal) ESCs and iPSCs have been derived from different developmental stages, such as morula, blastocyst (Sukoyan et al. 1993) and embryonic fibroblasts (Menzorov et al. 2015) respectively. However, the characterisation of mink PSCs was only based on methods such as $X$ chromosome status, glucose- 6 phosphate dehydrogenase (G6PD) activity, embryoid bodies (EB), teratoma formations and RNA-seq analysis. The mink PSCs were shown to express pluripotencyassociated markers, along with lineage-specific markers, such as Otx2 and Gata6, which hint towards a primed state, but these studies lack clarity. Despite this progress, there is a need for a more elaborate characterisation of mink ESCs with respect to the signalling pathways required to isolate and maintain them in culture and their ability to form germline chimeras. 
ESCs and iPSCs generated from rabbit depend on FGF2 and show features of primed pluripotency (Tables 1, 2 and Supplementary data 1) (Schmaltz-Panneau et al. 2014). When exposed to LIF, they show naïve-like characteristics (Tables 1, 2 and Supplementary data 1) (Honsho et al. 2015, Osteil et al. 2016, Tapponnier et al. 2017). Rabbit PSCs (rbPSCs) do not depend on LIF, neither LIF withdrawal nor JAK inhibition leads to differentiation in the presence of feeders (Tapponnier et al. 2017). But, RbESCs can be converted to a naïve-like state, using LIF, along with forskolin and CHIR990021 (Tables 1, 2 and Supplementary data 1) (Honsho et al. 2015), but failed to form germline chimeras, the golden standard indicative of naïve pluripotency. However, there is still a lack of clear understanding of the signalling pathways that support naïve and primed states of pluripotency of rbPSCs and this could be addressed with elaborate experiments under defined culture conditions, without feeders.

iPSCs derived from porcine/pigs resemble mEpiSCs and hESCs in terms of morphology and expression of pluripotency-associated markers and are likely dependent on FGF2/ACTIVIN/NODAL signalling. When porcine embryonic fibroblasts were reprogrammed to iPSCs in the presence of $2 \mathrm{i} / \mathrm{LIF}$, they resembled naïve mESCs in colony morphology and LIF dependence (Tables 1, 2 and Supplementary data 1) (Telugu et al. 2010). In the presence of three kinase inhibitors (GSK-3 $\beta$, MAPK, MEK), along with LIF, porcine ESCs and iPSCs exhibit naïve-like properties (Tables 1,2 and Supplementary data 1) (Li et al. 2003, Telugu et al. 2010, Petkov et al. 2016).

Bovine ESCs and iPSCs are also LIF dependent and have limited proliferation capacity. They acquire naïvelike characteristics, when grown in 2i/LIF (Cong et al. 2014, Kawaguchi et al. 2015, Talluri et al. 2015) and in the presence of FGF2/IWR1 (an inhibitor of canonical Wnt signalling pathway), bovine ESCs acquire a stable primed state of pluripotency (Tables 1,2 and Supplementary data 1) (Bogliotti et al. 2018).

In case of goat, ESCs are LIF dependent in nature and in the presence of FGF2, they show primed state-like characteristics (Tables 1, 2 and Supplementary data 1). Sheep iPSCs attain a naïve-like state, with an exposure of 2i/LIF and BMP4 (Behboodi et al. 2011, Sartori et al. 2012).

Similar to sheep and goat, horse-iPSCs show an FGF2dependent primed state of pluripotency (Tables 1, 2 and Supplementary data 1) (Nagy et al. 2011). Horse-derived ESCs differentiate into cells representative of the three germ layers, but failed to form teratomas (Li et al. 2006, Guest \& Allen 2007).

ESCs of canine and feline are in a primed state, with morphologies similar to EpiSCs of the mouse (Tables 1, 2 and Supplementary data 1). However, feline ESCs have limited self-renewal potential and lack teratoma formation capability (Gómez et al. 2010). The self- renewal property of canine PSCs can be improved by using LIF and FGF2 (Vaags et al. 2009, Koh et al. 2013).

Among the discussed mammals, germline chimera formation ability, 'the golden standard' of naïve pluripotency was not tested in most of these cases. A detailed understanding of the regulation of states of pluripotency in these mammalian ESCs and their culture conditions require further investigation and standardisation. It will be interesting to investigate if the dependence of naïve state on LIF and primed state on FGF2 are conserved among all mammals. An intriguing question that still needs to be addressed is, 'if a spectrum of pluripotent states exists, representing different developmental stages and if so, what is the exact signalling environment and differentiation potential of each of these states and their evolutionary conservation among mammals'.

\section{Pluripotency in primates}

Totipotency of human zygote persists until E3.5 (6- to 8-cell stage) and at E4, the first lineage segregation to TE and the ICM occurs at E4 stage (reviewed in De Paepe et al. 2014). Under conventional culture condition (FGF2 and ACTIVIN/TGF $\beta$ ), without any manipulations, hESCs exhibit primed state of pluripotency and are very similar to mEpiSCs. The states of pluripotency are interchangeable between the primed and naïve states, using suitable culture conditions, over-expression of the pluripotency factors by transgene expression (Table 2 and Supplementary data 1) (Bao et al. 2009, Guo et al. 2009, Hanna et al. 2009, Hanna et al. 2010, Xu et al. 2010) and modification of epigenetic factors (histone decetylase (HDAC) inhibition) (Guo et al. 2017). Naïve hESCs can be directly derived from individual cells of the ICM and maintained in t2iLGÖY medium (LIF, PD0325901, CHIR99021, GÖ6983 along with ROCK inhibitor (Y-27632) and ascorbic acid) (Guo et al. 2016). The molecular signature of human-naïve PSCs includes expression of pluripotency-associated markers, over-expression of members in the SINE-VNTR-Alu (SVA) family of transposable elements and epigenetic factors (X-chromosome status and DNA methylation) and developmental potential (interspecies chimera formation) (Theunissen et al. 2016). However, the generation of interspecies chimeras by injection of naive human cells into early mouse embryos was too sporadic for definitive assessment of functional contribution, as naive human cells rarely contributed to interspecies chimeras (Theunissen et al. 2014, 2016, Ware et al. 2014). Hence, till now, including interspecies chimera formation as a part of the molecular assessment of naive human pluripotency has not been widely accepted .

Like humans, iPSCs have been derived from NHPs, such as chimpanzee, bonobo, Gorilla and monkeys, by over-expression of the transcription factors-OCT3/4, SOX2, KLF4, C-MYC and LIN28 (Table 2, Liu et al. 2008, 
Chan et al. 2010, Tomioka et al. 2010, Wu et al. 2010, 2012, Ben-Nun et al. 2011, Deleidi et al. 2011, Okamoto \& Takahashi 2011, Hong et al. 2014, Wunderlich et al. 2014). In most of these studies, after successful reprogramming, the endogenous transcription factors were upregulated and the transgenes were downregulated (Liu et al. 2008, Chan et al. 2010, Tomioka et al. 2010, Wu et al. 2010, Ben-Nun et al. 2011).

Pluripotent cells of NHP share a lot of characteristics in common (Marchetto et al. 2014, Romero et al. 2015), but transcriptome analysis revealed significant variation among closely related primate species (Wunderlich et al. 2014). RNA sequencing and DNA methylation analysis of iPSCs of the closest relatives of human proved that their PSCs share a high degree of similarity between these species than their somatic counterparts (Romero et al. 2015). The differences in the regulation of long interspersed element-1 (LINE-1) transposons and the expression of $R E X 1$, between humans and NHPs highlight some of the evolutionary changes that might have occurred during the differential shaping of the genomes of humans and NHPs (Marchetto et al. 2014).

Unlike mouse naïve PSCs, the state of the naïve PSCs obtained from NHP was bFGF-dependent, in addition to $2 \mathrm{i} /$ LIF (Fang et al. 2014). The need for suppression of MAPK signalling in primate naïve PSCs is an intriguing question that arises, based on the role of other pathways, downstream of FGF signalling, such as PI3K/AKT and PLC $\gamma$ (Lanner \& Rossant 2010). Human-naive PSCs are dependent on TGF- $\beta$ signalling (Theunissen et al. 2014, Gafni et al. 2015), whereas monkey-naïve PSCs have been observed to be independent of the same (Fang et al. 2014). In case of rhesus monkey naïve PSCs, the inhibition of protein kinase $\mathrm{C}$ (PKC) and ROCKinduced differentiation (Fang et al. 2014); however, in human naïve PSCs, inhibition of PKC is essential for the maintenance of pluripotency (Chan et al. 2013, Gafni et al. 2015). Despite species-specific differences, it is not clear, if LIF dependence of the naïve state and the FGFdependence of the primed state, among PSCs of primates is conserved. This requires an enhanced understanding of signalling pathways and gene regulatory networks and comparative studies, involving synchronisation of culture conditions in PSCs from each species.

\section{Pluripotency in rodents}

Like mESCs, rat ESCs (rESCs) are capable of forming germline chimeras, but they express lineage-specific markers when cultured in 2i/LIF (Buehr et al. 2008, $\mathrm{Li}$ et al. 2008). In mESCs, the presence of inhibitors of MEK (MEKi) and GSK3 (CHIR99021) suppress the expression of lineage determining factors such as $C d x 2$ and $T$ (Smith et al. 1988; reviewed in Ye et al. 2014, Huang et al. 2015, Weinberger et al. 2016). In rat ESCs, the overinhibition of Gsk3 leads to the activation of differentiation-associated genes, such as $C d \times 2$ and $T$ and reduced inhibition of Gsk3 promotes clonogenicity and self-renewal, thus highlighting the importance of attaining an optimal level Gsk3 inhibition (Chen et al. 2013). ESCs derived from rodents can be maintained in a naïve state of pluripotency, when cultured in $2 \mathrm{i} /$ LIF (Meek et al. 2013) and show differentiation in the presence of FGF4 or FGF2 and ACTIVIN A/TGF $\beta$ enhancers (Tesar et al. 2007).

\section{Pluripotency in rodents vs primates}

Human and mouse embryos show morphological similarities during the development of pre-implantation blastocyst. They show considerable differences in their developmental stages (occurrence of zygotic genome activation (ZGA)), transcriptome and state of pluripotency (in vitro condition). The first embryonic lineages in the mouse are formed between E3 and E3.5, but in human, it happens at the E4 stage of development. The newly formed ICM in mouse and human pre-implantation blastocyst can act as an origin of ESCs of both species (reviewed in De Paepe et al. 2014, Wu \& Schöler 2016, Brink et al. 2008). In addition to ESCs, trophoblast stem cells (TS) and extra-embryonic endoderm stem cells (XEN) have been derived from mouse blastocysts (Chung et al. 2006, Yamanaka et al. 2006) and more recently, TS cells from human blastocysts (Okae et al. 2018).

In rodents, pluripotency and self-renewal of ESCs are strictly dependent on JAK/STAT3 signalling pathways (Fig. 2). BMP4, a possible molecule, which inhibits MEK/ERK activity and co-operates with LIF, contributes to self-renewal in mESCs (Ying et al. 2003, Qi et al. 2004, Schnerch et al. 2010). The features of standard primate ESCs are entirely distinct from rodent ESCs and pluripotency is entirely dependent on FGF2 and ACTIVIN A signalling pathways (reviewed in Schnerch et al. 2010, Warrier et al. 2017). Activation of the MEK/ ERK signalling pathway in rodent PSCs results in the differentiation. In contrast, in hESCs, FGF2 maintains a crosstalk between MEK/ERK and ACTIVIN/NODAL signalling pathways to enable pluripotency (Vallier et al. 2005, Li et al. 2007). IGF promotes the activation of PI3K/AKT signalling pathway, which is also crucial for stem cell self-renewal and pluripotency. The activity of MEK/ERK and PI3K/AKT pathways increases the levels of GSK3 within cytoplasm, which has a negative effect on $\beta$-catenin, resulting in the inhibition of WNT signalling pathway and maintaining the primed state of pluripotency in primates (reviewed in Huang et al. 2015).

Like PSCs, pluripotency properties of early embryonic stages among these mammals have also been explored by different groups. These studies concentrated on the role of signalling pathways (Boroviak et al. 2015) and transcription factors (Nakamura et al. 2016) involved in the maintenance of pluripotency in different developmental stages of primates and rodents. Along with different signalling pathways and transcription 


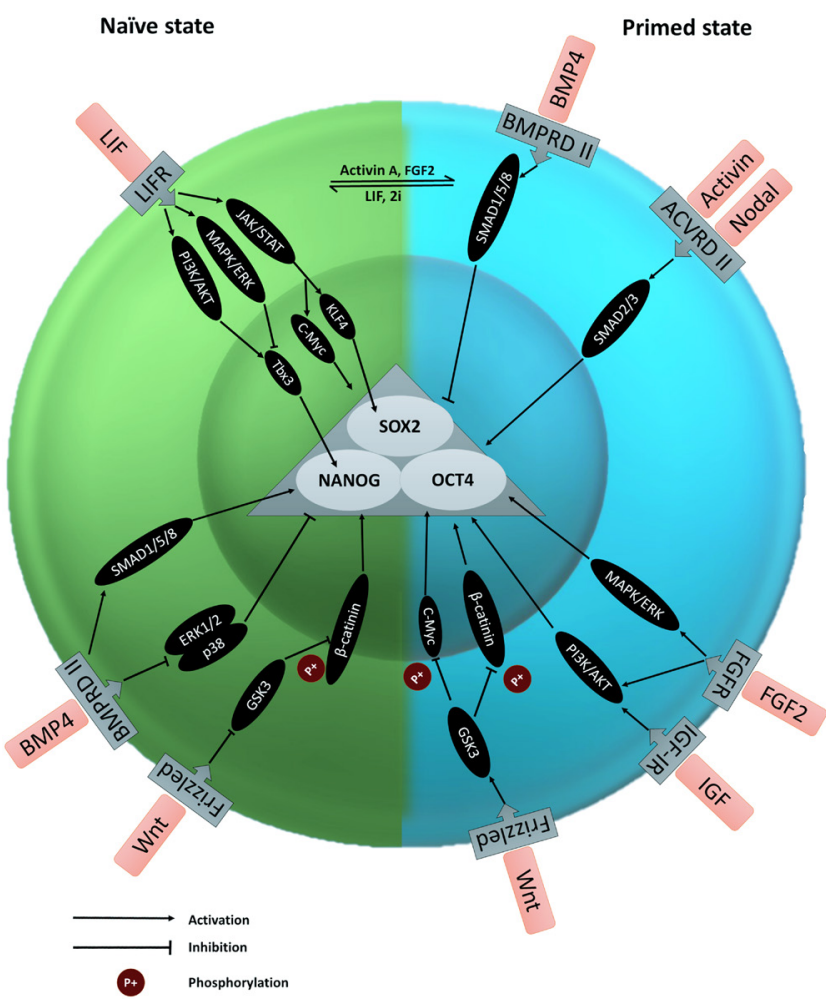

Figure 2 Signalling pathways regulating pluripotent states of PSCs.

factors, several transposable elements (TEs) are involved in maintaining the molecular harmony of pluripotency. The members of LTR and SRV families show an elevated expression level during different developmental stages of mammalian embryos (Goke et al. 2015; reviewed in Hutchins \& Pei 2015, Gerdes et al. 2016). More studies, concentrating on gene regulatory networks and signalling pathways involved in establishing and maintaining pluripotency and its distinct states-naïve and primed in primates and their comparison to other mammalian species would help in increasing our meagre understanding of the general principles of pluripotency conserved in evolution.

\section{Comparative analysis of pluripotency among primates and mouse}

We performed a comparative analysis of datasets from three species namely human (GSE75868; Theunissen et al. 2016), crab-eating macaque (Macaca fascicularis, GSE69708; Chen et al. 2015) and mouse (GSE99494; Bao et al. 2018), to identify common represented signalling pathways, irrespective of their differences. The studies concentrate on both naïve and primed states of pluripotency and satisfy the criteria, such as the source of donor cells, gene expression profiling, germline chimera-forming ability, cellular respiration profile, X-chromosome status, global DNA methylation, OCT4 enhancer utilisation, and so forth (Tables 1, 2 and Supplementary data 2). The dataset for the analysis was selected mainly on the basis of the platform used for sequencing, state of pluripotency (Table 2 and Supplementary data 2) and the origin of the cells. Bao et al. (2018) successfully derived advanced PSCs (ASCs) from EpiSCs, using Activin A, BMP4, CH and LIF. These cells are hyper-methylated with high levels of potency and can contribute to both embryonic and extraembryonic mesoderm in germline chimeras.

Our comparison unveiled both overlapping and distinctly regulated genes, between naïve and primed states of the three species (Fig. 3 and Supplementary Tables 3, 4, 5, 6, 7, 8, 9, 10). Here we have not discussed specific genes in detail, as this requires experimental validation. The most prominent observation from our
A

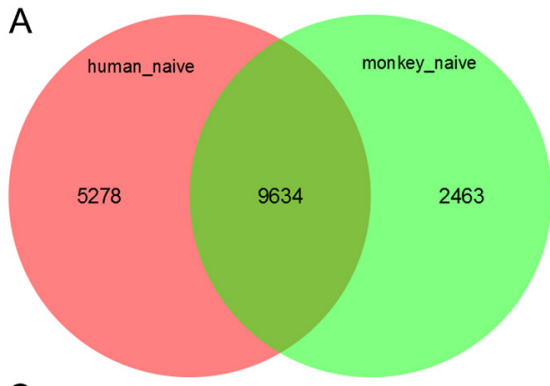

C

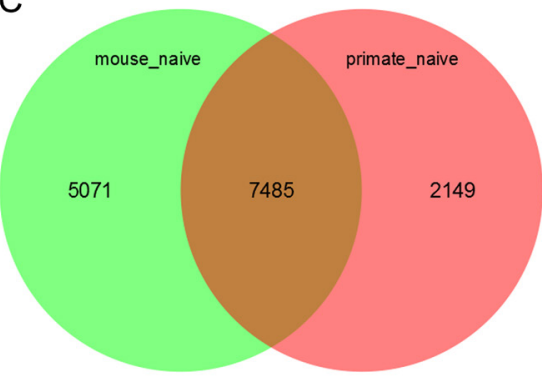

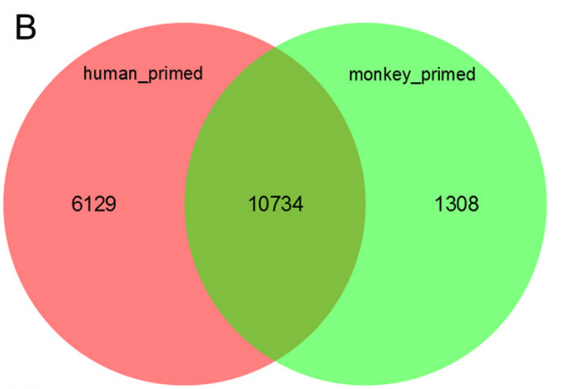

D

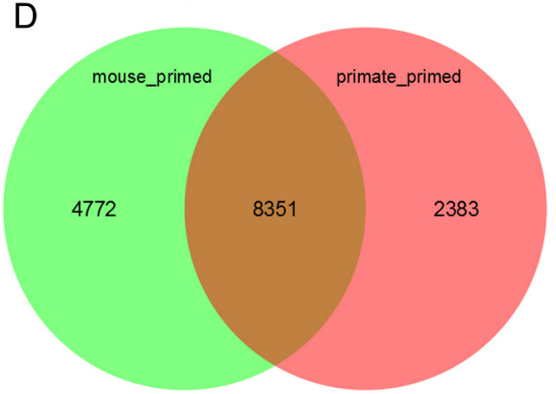

Figure 3 Comparative analysis of pluripotent states in primates (human, monkey) and rodents (mouse). (A) Naive state of human versus monkey, (B) primed state of human versus monkey, $(\mathrm{C})$ naive state of mouse versus primate (human and monkey) and (D) primed state of mouse versus primate (human and monkey). 
analysis is the common regulation of 12 signalling pathways in common between these species, irrespective of naïve or primed state of pluripotency (Supplementary Tables 6, 7, 8 and 9): Neurotrophin, thyroid hormone, FoxO, phosphatidylinositol, p53, AMPK, Hedgehog, Hippo, sphingolipid, mTOR, HIF-1 signalling pathway and insulin signalling pathway. This implies a probable conservation of these pathways during the course of evolution, in maintaining pluripotency and demand experimental validation.

Neurotrophin signalling pathway has a role in maintaining pluripotency and it also maintains a cross-talk with other signalling pathways involved in pluripotency (Pyle et al. 2006). Insulin signalling pathway and insulin-like growth factors (IGF) are also important for upholding pluripotency (Wang et al. 2007, Dalton 2013). mTOR pathway is very essential for the proliferation and survival of the pluripotent cells (Warrier et al. 2017). p53 is highly expressed in mouse ESCs in the cytoplasm under basal conditions (Aladjem et al. 1998, Solozobova et al. 2009) and functions to maintain genome stability in ESCs by inducing apoptosis upon DNA damage and differentiation (He et al. 2016). p53 reduces reprogramming efficiency of somatic cells to pluripotent stem cells and its inhibition enhances reprogramming efficiency (reviewed in Lin \& Lin 2017).

With respect to differences, the most prominent, included MAPK signalling, WNT signalling and VEGF signalling, which were found significantly over-represented ( $P$ and $q$ value $<0.05$ ) in the genes expressed in common in primates and mouse in the primed state, but not in the naïve state (Supplementary Tables 4 and 5). The differences in MAPK/ERK signalling between naïve and primed state are obvious as reflected by the inhibition of ERK signalling to induce the naïve state (Ying et al. 2008). The role of WNT signalling is controversial, because non-neural differentiation is induced upon WNT stimulation and residual neural differentiation is eliminated by WNT in the context of ERK and FGFR inhibition (Ying et al. 2008). Our finding of significant over-representation of WNT signalling in the primed state, compared to the naïve state could mainly be influenced by the culture conditions used for the naïve state in human which lacks the GSK3 inhibitor (4i) (Theunissen et al. 2016). Thus, while Ying et al. (2008) and Theunissen et al. (2016) induced the naïve state with and without the help of WNT induction, the advantages of WNT induction might be debatable.

Oxidative phosphorylation pathway $(P=0.02$, $q=0.08)$ was significantly over-represented in the naïve state, but not in the primed state, in the set, common between primate and mouse. This is in line with expectations concerning a shift of metabolism from oxidative phosphorylation to glycolysis in the maintenance of pluripotency (Prigione \& Adjaye 2010, Prigione et al. 2010, Carbognin et al. 2016, Weinberger et al. 2016).
In general, maintenance of pluripotency is achieved in a balanced state of self-renewal, differentiation, proliferation and cell survival, dependent on a wellorchestrated regulation of gene expression and a network of various signalling pathways (reviewed in Sui et al. 2013). The future challenges include standardisation of culture conditions that absolutely support naïve or primed state of pluripotency in mammals, other than human and mouse. Additionally, detailed investigation of pluripotency and the mechanisms for directed lineage specification in vitro, and a comprehensive analysis of gastrulation in each mammal will facilitate their comparison. For all the mammalian PSCs derived to date, other than germline chimera formation ability, that has been defined as the 'golden standard of naïve pluripotency', an additional test for their integration to tetraploid embryos, the most stringent test for pluripotency, would prove their potential, although this does not test for the ability to form extra-embryonic lineages (Wernig et al. 2007, Jaenisch \& Young 2008, Kang et al. 2009).

This is the era, where a spectrum of pluripotent states is being discovered. Investigation of a panel of EpiSC lines from mouse post-implantation embryos at embryonic day E5.5-E7.5 showed heterogeneity in the gene expression patterns and differentiation potential (Bernemann et al. 2011). Two distinct cell populations of mEpiSCs exist, which represent either early or late epiblast, the former possessing the ability to readily contribute to chimeras (Han et al. 2010). In contrast to the early-stage EpiSCs, the late-stage EpiSCs cannot be converted to naïve state with $2 \mathrm{i}$ medium, but require CK1 alpha inhibition for the same (Illich et al. 2016). As a clear understanding is still lacking, it will be interesting to find out more about the states of pluripotency, and a question remains, if pluripotent states, other than naïve and primed states, with varied differentiation potencies, representing different developmental stages exist. The existence of such states is beginning to be unveiled (Smith 2017, Bao et al. 2018). Another intriguing question that needs addressing is, do all mammalian PSCs rely on similar signalling environment to maintain their states of pluripotency and therefore preservation of evolutionary conservation.

\section{Methods}

\section{Bioinformatic analysis}

Datasets for human (GSE75868; Theunissen et al. 2016), crab-eating macaque (Macaca fascicularis, GSE69708; Chen et al. 2015) and mouse (GSE99494; Bao et al. 2018) were downloaded from NCBI GEO. Expressed genes were determined using a threshold for FPKM (fragments per kilobase of exon model per million reads mapped) $>0.1$ for the NGS data of monkey. For the NGS pileup and read data of human and mouse a threshold of $t=10$ was used. Expressed genes 
in ENSEBL gene notation were mapped to gene symbols via the ENSEMBL Biomart version 92 annotations. Interspecies comparisons were directly based on these symbols. Venn diagram analyses and KEGG (Kyoto Encyclopedia of Genes and Genomes) pathway over-representation analyses were performed in the R/Bioconductor (Gentleman et al. 2004) environment using the package Venndiagram (Chen \& Boutros 2011) and the test method phyper for the hypergeometric distribution. KEGG pathway data (Kanehisa et al. 2017) was downloaded from KEGG in March 2018 corresponding to version Release 85.1.

\section{Supplementary data}

This is linked to the online version of the paper at https://doi.org/10.1530/REP-18-0083.

\section{Declaration of interest}

The authors declare that there is no conflict of interest that could be perceived as prejudicing the impartiality of this review.

\section{Funding}

This research did not receive any specific grant from any funding agency in the public, commercial or not-for-profit sector.

\section{Acknowledgements}

J A acknowledges financial support from the Medical faculty of Heinrich Heine University, Düsseldorf, Germany. S S acknowledges financial support from Kerala State Council for Science, Technology \& Environment (KSCSTE) and Central University of Kerala, India. The authors thank Asha Shaji Antony and Athira Sajan for reading the article and helpful comments. J Adjaye and S Sudheer: Shared senior authorship.

\section{References}

Adjaye J, Huntriss J, Herwig R, BenKahla A, Brink TC, Wierling C, Hultschig C, Groth D, Yaspo ML, Picton HM et al. 2005 Primary differentiation in the human blastocyst: comparative molecular portraits of inner cell mass and trophectoderm cells. Stem Cells 23 1514-1525. (https://doi.org/10.1634/stemcells.2005-0113)

Aladjem MI, Spike BT, Rodewald LW, Hope TJ, Klemm M, Jaenisch R \& Wahl GM 1998 ES cells do not activate p53-dependent stress responses and undergo p53-independent apoptosis in response to DNA damage. Current Biology 8 145-155. (https://doi.org/10.1016/S09609822(98)70061-2)

Andrews PW, Matin MM, Bahrami AR, Damjanov I, Gokhale P \&Draper JS 2005 Embryonic stem (ES) cells and embryonal carcinoma (EC) cells: opposite sides of the same coin. Biochemical Society Transactions 33 1526-1530. (https://doi.org/10.1042/BST20051526)

Babaie Y, Herwig R, Greber B, Brink TC, Wruck W, Groth D, Lehrach H, Burdon T \& Adjaye J 2007 Analysis of Oct4-dependent transcriptional networks regulating self-renewal and pluripotency in human embryonic stem cells. Stem Cells 25 500-510. (https://doi.org/10.1634/ stemcells.2006-0426)

Bao S, Tang F, Li X, Hayashi K, Gillich A, Lao K \& Surani MA 2009 Epigenetic reversion of post-implantation epiblast to pluripotent embryonic stem cells. Nature 461 1292-1295. (https://doi.org/10.1038/nature08534)
Bao S, Tang WW, Wu B, Kim S, Li J, Li L, Kobayashi T, Lee C, Chen Y, Wei M et al. 2018 Derivation of hypermethylated pluripotent embryonic stem cells with high potency. Cell Research 28 22-34. (https://doi. org/10.1038/cr.2017.134)

Beddington RS \& Robertson EJ 1989 An assessment of the developmental potential of embryonic stem cells in the midgestation mouse embryo. Development 105 733-737.

Behboodi E, Bondareva A, Begin I, Rao K, Neveu N, Pierson JT, Wylie C, Piero FD, Huang YJ, Zeng W et al. 2011 Establishment of goat embryonic stem cells from in vivo produced blastocyst-stage embryos. Molecular Reproduction and Development 11 78-202. (https://doi.org/10.1002/ mrd.21290)

Ben-Nun IF, Montague SC, Houck ML, Tran HT, Garitaonandia I, Leonardo TR, Wang YC, Charter SJ, Laurent LC, Ryder OA et al. 2011 Induced pluripotent stem cells from highly endangered species. Nature Methods 8 829-831. (https://doi.org/10.1038/nmeth.1706)

Bernemann C, Greber B, Ko K, Sterneckert J, Han DW, Araúzo-Bravo MJ \& Schöler HR 2011 Distinct developmental ground states of epiblast stem cell lines determine different pluripotency features. Stem Cells 29 1496-1503. (https://doi.org/10.1002/stem.709)

Bogliotti YS, Wu J, Vilarino M, Okamura D, Soto DA, Zhong C, Sakurai M, Sampaio RV, Suzuki K, Izpisua Belmonte JC et al. 2018 Efficient derivation of stable primed pluripotent embryonic stem cells from bovine blastocysts. PNAS 115 2090-2095. (https://doi.org/10.1073/ pnas.1716161115)

Boroviak T, Loos R, Bertone P, Smith A \& Nichols J 2014 The ability of inner-cell-mass cells to self-renew as embryonic stem cells is acquired following epiblast specification. Nature Cell Biology 16 516-528. (https://doi.org/10.1038/ncb2965)

Boroviak T, Loos R, Lombard P, Okahara J, Behr R, Sasaki E, Nichols J, Smith A \& Bertone P 2015 Lineage-specific profiling delineates the emergence and progression of naive pluripotency in mammalian

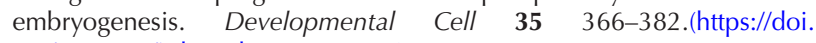
org/10.1016/j.devcel.2015.10.011)

Brons IG, Smithers LE, Trotter MW, Rugg-Gunn P, Sun B, Chuva de Sousa Lopes SM, Howlett SK, Clarkson A, Ahrlund-Richter L, Pedersen RA et al. 2007 Derivation of pluripotent epiblast stem cells from mammalian embryos. Nature 448 191-195. (https://doi. org/10.1038/nature05950)

Brink TC, Sudheer S, Janke D, Jagodzinska J, Jung M \& Adjaye J 2008 The origins of human embryonic stem cells: a biological conundrum. Cells, Tissues, Organs 188 9-22. (https://doi.org/10.1159/000112843)

Buehr M, Meek S, Blair K, Yang J, Ure J, Silva J, McLay R, Hall J, Ying QL \& Smith A 2008 Capture of authentic embryonic stem cells from rat blastocysts. Cell 135 1287-1298. (https://doi.org/10.1016/j. cell.2008.12.007)

Carbognin E, Betto RM, Soriano ME, Smith AG \& Martello G 2016 Stat3 promotes mitochondrial transcription and oxidative respiration during maintenance and induction of naive pluripotency. EMBO Journal 35 618-634. (https://doi.org/10.15252/embj.201592629)

Chan AWS, Cheng PH, Neumann A \& Yang JJ 2010 Reprogramming Huntington monkey skin cells into pluripotent stem cells. Cellular Reprogramming 12 509-517. (https://doi.org/10.1089/ cell.2010.0019)

Chan YS, Göke J, Ng JH, Lu X, Gonzales KAU, Tan CP, Tng WQ, Hong ZZ, Lim YS \& Ng HH 2013 Induction of a human pluripotent state with distinct regulatory circuitry that resembles preimplantation epiblast. Cell Stem Cell 13 663-675. (https://doi.org/10.1016/j.stem.2013.11.015)

Chen H \& Boutros PC 2011 VennDiagram: a package for the generation of highly-customizable Venn and Euler diagrams in R. BMC Bioinformatics 12 35. (https://doi.org/10.1186/1471-2105-12-35)

Chen Y, Blair K \& Smith A 2013 Robust self-renewal of rat embryonic stem cells requires fine-tuning of glycogen synthase kinase-3 inhibition. Stem Cell Reports 1 209-217. (https://doi.org/10.1016/j.stemcr.2013.07.003)

Chen Y, Niu Y, Li Y, Ai Z, Kang Y, Shi H, Xiang Z, Yang Z, Tan T, Si W et al. 2015 Generation of cynomolgus monkey chimeric fetuses using embryonic stem cells. Cell Stem Cell 17 116-124. (https://doi. org/10.1016/j.stem.2015.06.004)

Chung Y, Klimanskya I, Becker S, Marh J,Lu SJ, Johnson J, Meisner L \& Lanza R 2006 Embryonic and extraembryonic stem cell lines derived from single mouse blastomeres. Nature 439 216-219. (https://doi. org/10.1038/nature04277) 
Cong S, Cao G \& Liu D 2014 Effects of different feeder layers on culture of bovine embryonic stemcell-like cells in vitro. Cytotechnology $\mathbf{6 6}$ 995-1005. (https://doi.org/10.1007/s10616-013-9653-4)

Dalton S 2013 Signaling networks in human pluripotent stem cells. Current Opinion in Cell Biology 25 241-246. (https://doi.org/10.1016/j. ceb.2012.09.005)

Das P, Ezashi T, Schulz LC, Westfall SD, Livingston KA \& Roberts RM 2007 Effects of FGF2 and oxygen in the bmp4-driven differentiation of trophoblast from human embryonic stem cells. Stem Cell Research 1 61-74. (https://doi.org/10.1016/j.scr.2007.09.004)

Davidson EH, Rast JP, Oliveri P, Ransick A, Calestani C, Yuh CH, Minokawa T, Amore G, Hinman V, Arenas-Mena C et al. 2002 A genomic regulatory network for development. Science 295 1669-1678.

De Paepe C, Krivega M, Cauffman G, Geens M \& Van de Velde H 2014 Totipotency and lineage segregation in the human embryo. Molecular Human Reproduction 20 599-618. (https://doi.org/10.1093/molehr/ gau027)

Dejosez M \& Zwaka TP 2012 Pluripotency and nuclear reprogramming. Annual Review of Biochemistry 81 737-765. (https://doi.org/10.1146/ annurev-biochem-052709-104948)

Deleidi M, Hargus G, Hallett P, Osborn T \& Isacson O 2011 Development of histocompatible primate induced pluripotent stem cells for neural transplantation. Stem Cells 29 1052-1063. (https://doi.org/10.1002/ stem.662)

Delhaise F, Bralion V, Schuurbiers N \& Dessy F 1996 Establishment of an embryonic stem cell line from 8-cell stage mouse embryos. European Journal of Morphology 34 237-243. (https://doi.org/10.1076/ ejom.34.4.237.13046)

Dutta D, Ray S, Home P, Larson M, Wolfe MW, Paul SS, Wolfe WM \& Paul SS 2011 Self renewal vs. lineage commitment of embryonic stem cells: protein kinase C signaling shifts the balance. Stem Cells 29 618-628. (https://doi.org/10.1002/stem.605)

Evans MJ \& Kaufman MH 1981 Establishment in culture of pluripotential cells from mouse embryos. Nature 292 154-156. (https://doi. org/10.1038/292154a0)

Ezashi T, Yuan Y \& Roberts RM 2016 Pluripotent stem cells from domesticated mammals. Annual Review of Animal Biosciences 4 223-253. (https://doi.org/10.1146/annurev-animal-021815-111202)

Fang R, Liu K, Zhao Y, Li H, Zhu D, Du Y, Xiang C, Li X, Liu H, Miao Z et al. 2014 Generation of naive induced pluripotent stem cells from rhesus monkey fibroblasts. Cell Stem Cell 15 488-497. (https://doi. org/10.1016/j.stem.2014.09.004)

Gafni O, Weinberger L, Mansour AA, Manor YS, Chomsky E, Ben-Yosef D, Kalma Y, Viukov S, Maza I, Zviran A et al. 2015 Corrigendum: derivation of novel human ground state naive pluripotent stem cells. Nature $\mathbf{5 2 0}$ 710-710. (https://doi.org/10.1038/nature14370)

Gentleman RC, Carey VJ, Bates DM, Bolstad B, Dettling M, Dudoit S, Ellis B, Gautier L, Ge Y, Gentry J et al. 2004 Bioconductor: open software development for computational biology and bioinformatics. Genome Biology 5 R80. (https://doi.org/10.1186/gb-2004-5-10-r80)

Gerdes P, Richardson SR, Mager DL \& Faulkner GJ 2016 Transposable elements in the mammalian embryo: pioneers surviving through stealth and service. Genome Biology 17 100. (https://doi.org/10.1186/s13059016-0965-5)

Goke J, Lu X, Chan YS, Ng HH, Ly LH, Sachs F \& Szczerbinska I 2015 Dynamic transcription of distinct classes of endogenous retroviral elements marks specific populations of early human embryonic cells. Cell Stem Cell 16 135-141. (https://doi.org/10.1016/j.stem.2015.01.005)

Gómez MC, Serrano MA, Pope CE, Jenkins JA, Biancardi MN, López M, Dumas C, Galiguis J \& Dresser BL 2010 Derivation of cat embryonic stem-like cells from in vitro-produced blastocysts on homologous and heterologous feeder cells. Theriogenology 74 498-515. (https://doi. org/10.1016/j.theriogenology.2010.05.023)

Greber B, Lehrach H \& Adjaye J 2007a Silencing of core transcriptions factors in human EC cells highlights the importance of autocrine FGF signalling for self-renewal. BMC Developmental Biology 7 46. (https:// doi.org/10.1186/1471-213X-7-46)

Greber B, Lehrach H \& Adjaye J 2007 b Fibroblast growth factor 2 modulates transforming growth factor beta signalling in mouse embryonic fibroblasts and human ESCs (hESCs) to support hESC self-renewal. Stem Cells 25 455-464. (https://doi.org/10.1634/stemcells.2006-0476)
Guest DJ \& Allen WR 2007 Expression of Cell-Surface Antigens and Embryonic Stem Cell. Stem Cells and Development 16 789-795. (https:// doi.org/10.1089/scd.2007.0032)

Guo G, Yang J, Nichols J, Hall JS, Eyres I, Mansfield W \& Smith A 2009 KIf4 reverts developmentally programmed restriction of ground state pluripotency. Development 136 1063-1069. (https://doi.org/10.1242/ dev.030957)

Guo G, Von Meyenn F, Santos F, Chen Y, Reik W, Bertone P, Smith A \& Nichols J 2016 Naive pluripotent stem cells derived directly from isolated cells of the human inner cell mass. Stem Cell Reports 6 437-446. (https:// doi.org/10.1016/j.stemcr.2016.02.005)

Guo G, Von Meyenn F, Rostovskaya M, Clarke J, Dietmann S, Baker D, Sahakyan A, Myers S, Bertone P, Reik W et al. 2017 Correction: epigenetic resetting of human pluripotency. Sem Cell and Regeneration 144166397.

Hamanaka S, Yamaguchi T, Kobayashi T, Kato-Itoh M, Yamazaki S, Sato H, Umino A, Wakiyama Y, Arai M, Sanbo M et al. 2011 Generation of germline-competent rat induced pluripotent stem cells. PLOS ONE 6 e22008. (https://doi.org/10.1371/journal.pone.0022008)

Han DW, Tapia N, Joo JY, Greber B, Araúzo-Bravo MJ, Bernemann C, Ko K, Wu G, Stehling M, Do JT et al. 2010 Epiblast stem cell subpopulations represent mouse embryos of distinct pregastrulation stages. Cell 143 617-627. (https://doi.org/10.1016/j.cell.2010.10.015)

Hanna J, Markoulaki S, Mitalipova M, Cheng AW, Cassady JP, Staerk J, Carey BW, Lengner CJ, Foreman R, Love J et al. 2009 Metastable pluripotent states in NOD mouse derived ES cells. Cell Stem Cell $\mathbf{4}$ 513-524. (https://doi.org/10.1016/j.stem.2009.04.015)

Hanna J, Cheng AW, Saha K, Kim J, Lengner CJ, Soldner F, Cassady JP, Muffat J, Carey BW \& Jaenisch R 2010 Human embryonic stem cells with biological and epigenetic characteristics similar to those of mouse ESCs. PNAS 107 9222-9227. (https://doi.org/10.1073/pnas.1004584107)

He H, Wang C, Dai Q, Li F, Bergholz J, Li Z, Li Q \& Xiao ZX 2016 p53 and p73 regulate apoptosis but not cell-cycle progression in mouse embryonic stem cells upon DNA damage and differentiation. Stem Cell Reports 7 1087-1098. (https://doi.org/10.1016/j. stemcr.2016.10.008)

Honda A, Kawano Y, Izu H, Choijookhuu N, Honsho K, Nakamura T, Yabuta Y, Yamamoto T, Takashima Y, Hirose M et al. 2017 Discrimination of stem cell status after subjecting cynomolgus monkey pluripotent stem cells to naïve conversion. Scientific Reports 7 45285. (https://doi. org/10.1038/srep45285)

Hong SG, Winkler T, Wu C, Guo V, Pittaluga S, Donahue RE, Metzger ME, Price SD, Uchida N, Kuznetsov A et al. 2014 Path to the Clinic: assessment of iPSC-based cell therapies in vivo in a nonhuman primate model. Cell Reports 7 1-12. (https://doi.org/10.1016/j.celrep.2014.04.019)

Honsho K, Hirose M, Hatori M, Yasmin L, Izu H, Matoba S, Togayachi S, Miyoshi H, Sankai T, Ogura A et al. 2015 Naïve-like conversion enhances the difference in innate in vitro differentiation capacity between rabbit ES cells and iPS cells. Journal of Reproduction and Development $\mathbf{6 1}$ 13-19. (https://doi.org/10.1262/jrd.2014-098)

Horii M, Li Y, Wakeland AK, Pizzo DP, Nelson KK, Sabatini K, Laurent LC, Liu Y \& Parast MM 2016 Human pluripotent stem cells as a model of trophoblast differentiation in both normal development and disease. PNAS 113 E3882-E3891. (https://doi.org/10.1073/pnas.1604747113)

Huang G, Ye S, Zhou X, Liu D \& Ying QL 2015 Molecular basis of embryonic stem cell self-renewal: from signaling pathways to pluripotency network. Cellular and Molecular Life Sciences 72 1741-1757. (https://doi. org/10.1007/s00018-015-1833-2)

Hutchins AP \& Pei D 2015 Transposable elements at the center of the crossroads between embryogenesis, embryonic stem cells, reprogramming, and long non-coding RNAs. Science Bulletin 60 1722-1733. (https://doi.org/10.1007/s11434-015-0905-x)

Illich DJ, Zhang M, Ursu A, Osorno R, Kim KP, Yoon J, Araúzo-Bravo MJ, Wu G, Esch D, Sabour D et al. 2016 Distinct signaling requirements for the establishment of ESC pluripotency in late-stage EpiSCs. Cell Reports 15 787-800. (https://doi.org/10.1016/j.celrep.2016.03.073)

Jaenisch R \& Young R 2008 Stem cells, the molecular circuitry of pluripotency and nuclear reprogramming. Cell 132 567-582. (https:// doi.org/10.1016/j.cell.2008.01.015)

Jung M, Peterson H, Chavez L, Kahlem P, Lehrach H, Vilo J \& Adjaye J 2010 A data integration approach to mapping OCT4 gene regulatory networks 
operative in embryonic stem cells and embryonal carcinoma cells. PLoS ONE 5 e10709. (https://doi.org/10.1371/journal.pone.0010709)

Kanehisa M, Furumichi M, Tanabe M, Sato Y \& Morishima K 2017 KEGG: new perspectives on genomes, pathways, diseases and drugs. Nucleic Acids Research 45 D353-D361. (https://doi.org/10.1093/nar/gkw1092)

Kang L, Wang J, Zhang Y, Kou Z \& Gao S 2009 iPS cells can support fullterm development of tetraploid blastocyst-complemented embryos. Cell Stem Cell 5 135-138. (https://doi.org/10.1016/j.stem.2009.07.001)

Kawaguchi T, Tsukiyama T, Kimura K, Matsuyama S, Minami N,Yamada M \& Imai H 2015 Generation of naïve bovine inducedpluripotent stem cells using piggyBac transposition of doxycycline-inducible transcription factors. Public Library of Science 10 e0135403. (https://doi.org/10.1371/ journal.pone.0135403)

Kawase E, Suemori H \& Takahashi N 1994 Strain diference in establishment of mouse embryonic stem (ES) cell lines. International Journal of Developmental Biology 38 385-390.

Kelly SJ 1977 Studies of the developmental potential of 4- and 8-cell stage mouse blastomeres. Journal of Experimental Zoology 200 365-376. (https://doi.org/10.1002/jez.1402000307)

Kerr CL, Gearhart JD, Elliott AM \& Donovan PJ 2006 Embryonic germ cells: when germ cells become stem cells. Seminars in Reproductive Medicine 24 304-313. (https://doi.org/10.1055/s-2006-952152)

Koh S, Thomas R, Tsai S, Bischoff S, Lim JH, Breen M, Olby NJ \& Piedrahita JA 2013 Growth requirements and chromosomal instability of induced pluripotent stem cells generated from adult canine fibroblasts. Stem Cells and Development 22 951-963. (https://doi.org/10.1089/ scd.2012.0393)

Kojima J, Fukuda A, Taira H, Kawasaki T, Ito H, Kuji N, Isaka K, Umezawa A \& Akutsu H 2017 Efficient production of trophoblast lineage cells from human induced pluripotent stem cells. Laboratory Investigation 97 1188-1200. (https://doi.org/10.1038/labinvest.2016.159)

Lanner F \& Rossant J 2010 The role of FGF/Erk signaling in pluripotent cells. Development 137 3351-3360. (https://doi.org/10.1242/dev.050146)

Leitch HG \& Smith A 2013 The mammalian germline as a pluripotency cycle. Development 140 2495-2501. (https://doi.org/10.1242/ dev.091603)

Leitch HG, Blair K, Mansfield W, Ayetey H, Humphreys P, Nichols J, Surani MA \& Smith A 2010 Embryonic germ cells from mice and rats exhibit properties consistent with a generic pluripotent ground state. Development 137 2279-2287. (https://doi.org/10.1242/dev.050427)

Leung CY \& Zernicka-Goetz M 2015 Mapping the journey from totipotency to lineage specification in the mouse embryo. Current Opinion in Genetics and Development 34 71-76. (https://doi.org/10.1016/j. gde.2015.08.002)

Li M \& Belmonte JC 2017 Ground rules of the pluripotency gene regulatory network. Nature Reviews: Genetics 18 180-191. (https://doi. org/10.1038/nrg.2016.156)

Li M, Zhang D, Hou Y, Jiao L, Zheng X \& Wang WH 2003 Isolation and culture of embryonic stem cells from porcine blastocysts. Molecular Reproduction and Development 65 429-434. (https://doi.org/10.1002/ mrd.10301)

Li X, Zhou SG, Imreh MP, Ahrlund-Richter L \& Allen WR 2006 Horse embryonic stem cell lines from the proliferation of inner cell mass cells. Stem Cells and Development 15 523-531. (https://doi.org/10.1089/ scd.2006.15.523)

Li J, Wang G, Wang C, Zhao Y, Zhang H, Tan Z, Song Z, Ding M \& Deng H 2007 MEK/ERK signaling contributes to the maintenance of human embryonic stem cell self-renewal. Differentiation: Research in Biological Diversity 75 299-307. (https://doi.org/10.1111/j.14320436.2006.00143.x)

Li P, Tong C, Mehrian-Shai R, Jia L, Wu N, Yan Y, Maxson RE, Schulze EN, Song H, Hsieh CL et al. 2008 Germline competent embryonic stem cells derived from rat blastocysts. Cell 135 1299-1310. (https://doi. org/10.1016/j.cell.2008.12.006)

Lin T \& Lin Y 2017 p53 switches off pluripotency on differentiation. Stem Cell Research and Therapy 8 44. (https://doi.org/10.1186/s13287-017-0498-1)

Liu H, Zhu F, Yong J, Zhang P, Hou P, Li H, Jiang W, Cai J, Liu M, Cui K et al. 2008 Generation of induced pluripotent stem cells from adult rhesus monkey fibroblasts. Cell Stem Cell 3 587-590. (https://doi.org/10.1016/j. stem.2008.10.014)

Marchetto MCN, Narvaiza I, Denli AM, Benner C, Lazzarini A, Nathanson JL, Paquola ACM, Desai KN, Roberto H, Weitzman MD et al. 2014 Differential LINE-1 regulation in pluripotent stem cells of humans and other great apes. Nature 503 525-529.

Martello G \& Smith A 2014 The nature of embryonic stem cells. Annual Review of Cell and Developmental Biology 30 647-675. (https://doi. org/10.1146/annurev-cellbio-100913-013116)

Martin GR 1981 Isolation of a pluripotent cell line from early mouse embryos cultured in medium conditioned by teratocarcinoma stem cells. PNAS 78 7634-7638. (https://doi.org/10.1073/pnas.78.12.7634)

Matsui Y, Zsebo K \& Hogan BL 1992 Derivation of pluripotential embryonic stem cells from murine primordial germ cells in culture. Cell $\mathbf{7 0}$ 841-847. (https://doi.org/10.1016/0092-8674(92)90317-6)

Meek S, Wei J, Sutherland L, Nilges B, Buehr M, Tomlinson SR, Thomson AJ \& Burdon T 2013 Tuning of $\beta$-catenin activity is required to stabilize selfrenewal of rat embryonic stem cells. Stem Cells 31 2104-2115. (https:// doi.org/10.1002/stem.1466)

Menzorov AG, Matveeva NM, Markakis MN, Fishman VS, Christensen K, Khabarova AA, Pristyazhnyuk IE, Kizilova EA, Cirera S, Anistoroaei R et al. 2015 Comparison of American mink embryonic stem and induced pluripotent stem cell transcriptomes. BMC Genomics 16 S6. (https://doi. org/10.1186/1471-2164-16-S13-S6)

Morgani SM, Canham MA, Nichols J, Sharov AA, Migueles RP, Ko MSH \& Brickman JM 2013 Totipotent embryonic stem cells arise in ground-state culture conditions. Cell Reports 3 1945-1957. (https://doi.org/10.1016/j. celrep.2013.04.034)

Mueller S, Prelle K, Rieger N, Petznek H, Lassnig C, Luksch U, Aigner B, Baetscher M, Wolf E, Mueller M et al. 1999 Chimeric pigs following blastocyst injection of transgenic porcine primordial germ cells. Molecular Reproduction and Development 54 244-254. (https://doi.org/10.1002/ (SICI)1098-2795(199911)54:3<244::AID-MRD5>3.0.CO;2-5)

Nagy K, Sung HK, Zhang P, Laflamme S, Vincent P, Agha-Mohammadi S, Woltjen K, Monetti C, Michael IP, Smith LC et al. 2011 Induced pluripotent stem cell lines derived from equine fibroblasts. Stem Cell Reviews 7 693-702. (https://doi.org/10.1007/s12015-011-9239-5)

Nakamura T, Okamoto I, Sasaki K, Yabuta Y, Iwatani C, Tsuchiya H, Seita Y, Nakamura S, Yamamoto T \& Saitou M 2016 A developmental coordinate of pluripotency among mice, monkeys and humans. Nature 537 57-62. (https://doi.org/10.1038/nature19096)

Niakan KK, Ji H, Maehr R, Vokes SA, Rodolfa KT, Sherwood RI, Yamaki M, Dimos JT, Chen AE, Melton DA et al. 2010 Sox 17 promotes differentiation in mouse embryonic stem cells by directly regulating extraembryonic gene expression and indirectly antagonizing self-renewal. Genes and Development 24 312-326. (https://doi.org/10.1101/gad.1833510)

Nichols J \& Smith A 2009 Naive and primed pluripotent states. Cell Stem Cell 4 487-492. (https://doi.org/10.1016/j.stem.2009.05.015)

Nichols J \& Smith A 2012 Pluripotency in the embryo and in culture. Cold Spring Harborperspectives in Biology 8 1-4.

Nichols J, Jones K, Phillips JM, Newland SA, Roode M, Mansfield W, Smith A \& Cooke A 2009 Validated germline-competent embryonic stem cell lines from nonobese diabetic mice. Nature Medicine 15 814-818. (https://doi.org/10.1038/nm.1996)

Nikolic A, Volarevic V, Armstrong L, Lako M \& Stojkovic M 2016 Primordial germ cells: current knowledge and perspectives. Stem Cells International 2016 1741072. (https://doi.org/10.1155/2016/1741072)

Niwa H, Burdon T, Chambers I \& Smith A 1998 Self-renewal of pluripotent embryonic stem cells is mediated via activation of STAT3. Genes and Development 12 2048-2060. (https://doi.org/10.1101/gad.12.13.2048)

Niwa H, Ogawa K, Shimosato D \& Adachi K 2009 A parallel circuit of LIF signalling pathways maintains pluripotency of mouse ES cells. Nature 460 118-122. (https://doi.org/10.1038/nature08113)

Ogorevc J, Orehek S \& Dovč P 2016 Cellular reprogramming in farm animals: an overview of iPSC generation in the mammalian farm animal species. Journal of Animal Science and Biotechnology 7 10. (https://doi. org/10.1186/s40104-016-0070-3)

Okae H, Toh H, Sato T, Hiura H, Takahashi S, Shirane K \& Kabayama Y 2018 Derivation of human trophoblast stem cells article derivation of human trophoblast stem cells. Stem Cell 22 e6. (https://doi.org/10.1016/j. stem.2017.11.004)

Okamoto S \& Takahashi M 2011 Induction of retinal pigment epithelial cells from monkey iPS cells. Investigative Ophthalmology and Visual Science 52 8785-8790. (https://doi.org/10.1167/iovs.11-8129)

Onishi K, Tonge PD, Nagy A \& Zandstra PW 2014 Local BMP-SMAD1 signaling increases LIF receptor-dependent STAT3 responsiveness and 
primed-to-naive mouse pluripotent stem cell conversion frequency. Stem Cell Reports 3 156-168. (https://doi.org/10.1016/j.stemcr.2014.04.019)

Osorno R, Tsakiridis A, Wong F, Cambray N, Economou C, Wilkie R, Blin G, Scotting PJ, Chambers I \& Wilson V 2012 The developmental dismantling of pluripotency is reversed by ectopic Oct4 expression. Development 139 2288-2298. (https://doi.org/10.1242/dev.078071)

Osteil P, Moulin A, Santamaria C, Joly T, Jouneau L, Aubry M, Tapponnier Y, Archilla C, Schmaltz-Panneau B, Lecardonnel J et al. 2016 A panel of embryonic stem cell lines reveals the variety and dynamic of pluripotent states in rabbits. Stem Cell Reports 7 383-398. (https://doi.org/10.1016/j. stemcr.2016.07.022)

Pera MF, Andrade J, Houssami S, Reubinoff B, Trounson A, Stanley EG, Ward-van Oostwaard D \& Mummery C 2004 Regulation of human embryonic stem cell differentiation by BMP-2 and its antagonist noggin. Journal of Cell Science 117 1269-1280. (https://doi.org/10.1242/ jcs.00970)

Petkov S, Glage S, Nowak-Imialek M \& Niemann H 2016 Long-term culture of porcine induced pluripotent stem-like cells under feederfree conditions in the presence of histone deacetylase inhibitors. Stem Cells and Development 25 386-394. (https://doi.org/10.1089/ scd.2015.0317)

Prigione A \& Adjaye J 2010 Modulation of mitochondrial biogenesis and bioenergetic metabolism upon in vitro and in vivo differentiation of human ES and iPS cells. International Journal of Developmental Biology 54 1729-1741. (https://doi.org/10.1387/ijdb.103198ap)

Prigione A, Fauler B, Lurz R, Lehrach H \& Adjaye J 2010 The senescencerelated mitochondrial/oxidative stress pathway is repressed in human induced pluripotent stem cells. Stem Cells 28 721-733. (https://doi. org/10.1002/stem.404)

Pyle AD, Lock LF \& Donovan PJ 2006 Neurotrophins mediate human embryonic stem cell survival. Nature Biotechnology 24 344-350. (https://doi.org/10.1038/nbt1189)

Qi X, Li TG, Hao J, Hu J, Wang J, Simmons H, Miura S, Mishina Y \& Zhao GQ 2004 BMP4 supports self-renewal of embryonic stem cells by inhibiting mitogen-activated protein kinase pathways. PNAS $\mathbf{1 0 1}$ 6027-6032. (https://doi.org/10.1073/pnas.0401367101)

Rajendran G, Dutta D, Hong J, Paul A, Saha B, Mahato B, Ray S, Home P, Ganguly A, Weiss ML et al. 2013 Inhibition of protein kinase c signaling maintains rat embryonic stem cell pluripotency. Journal of Biological Chemistry 288 24351-24362. (https://doi.org/10.1074/jbc. M113.455725)

Resnick JL, Bixler LS, Cheng L \& Donovan PJ 1992 Long-term proliferation of mouse primordial germ cells in culture. Nature 359 550-551. (https:// doi.org/10.1038/359550a0)

Roberts RM, Loh KM, Amita M, Bernardo AS, Adachi K, Alexenko AP, Schust DJ, Schulz LC, Telugu BPVL, Ezashi T et al. 2014 Differentiation of trophoblast cells from human embryonic stem cells: to be or not to be? Reproduction 147 D1-D12. (https://doi.org/10.1530/REP-14-0080)

Romero IG, Pavlovic BJ, Hernando-Herraez I, Zhou X, Ward MC, Banovich NE, Kagan CL, Burnett JE, Huang CH, Mitrano A et al. 2015 A panel of induced pluripotent stem cells from chimpanzees: a resource for comparative functional genomics. elife 4 e07103. (https://doi. org/10.7554/eLife.07103)

Sartori C, DiDomenico AI, Thomson AJ, Milne E, Lillico SG, Burdon TG \& Whitelaw CB 2012 Ovine-induced pluripotent stem cells can contribute to chimeric lambs. Cellular Reprogramming 14 8-19. (https://doi. org/10.1089/cell.2011.0050)

Schmaltz-Panneau B, Jouneau L, Osteil P, Tapponnier Y, Afanassieff M, Moroldo M, Jouneau A, Daniel N, Archilla C, Savatier P et al. 2014 Contrasting transcriptome landscapes of rabbit pluripotent stem cells in vitro and in vivo. Animal Reproduction Science 149 67-79. (https://doi. org/10.1016/j.anireprosci.2014.05.014)

Schnerch A, Cerdan C \& Bhatia M 2010 Distinguishing between mouse and human pluripotent stem cell regulation: the best laid plans of mice and men. Stem Cells 28 419-430. (https://doi.org/10.1002/stem.298)

Shamblott MJ, Axelman J, Wang S, Bugg EM, Littlefield JW, Donovan PJ, Blumenthal PD, Huggins GR \& Gearhart JD 1998 Derivation of pluripotent stem cells from cultured human primordial germ cells. PNAS 95 13726-13731. (https://doi.org/10.1073/pnas.95.23.13726)

Sherstyuk VV, Medvedev SP, Elisaphenko EA, Vaskova EA, Ri MT, Vyatkin YV, Saik OV, Shtokalo DN, Pokushalov EA \& Zakian SM 2017 Genome-wide profiling and differential expression of microRNA in rat pluripotent stem cells. Scientific Reports 7 2787. (https://doi. org/10.1038/s41598-017-02632-0)

Shimizu T, Ueda J, Ho JC, Iwasaki K, Poellinger L, Harada I \& Sawada Y 2012 Dual inhibition of Src and GSK3 maintains mouse embryonic stem cells, whose differentiation is mechanically regulated by Src signaling. Stem Cells 30 1394-1404. (https://doi.org/10.1002/stem.1119)

Smith A 2017 Formative pluripotency: the executive phase in a developmental continuum. Development 144 365-373. (https://doi. org/10.1242/dev.142679)

Smith AG, Heath JK, Donaldson DD, Wong GG, Moreau J, Stahl M \& Rogers D 1988 Inhibition of pluripotential embryonic stem cell differentiation by purified polypeptides. Nature 336 688-690. (https:// doi.org/10.1038/336688a0)

Solozobova V, Rolletschek A \& Blattner C 2009 Nuclear accumulation and activation of p53 in embryonic stem cells after DNA damage. BMC Cell Biology 11 1-11. (https://doi.org/10.1186/1471-2121-10-46)

Solter D, Skreb N \& Damjanov I 1970 Extrauterine growth of mouse eggcylinders results in malignant teratoma. Nature 227 503-504. (https:// doi.org/10.1038/227503a0)

Stevens LC 1970 The development of transplantable teratocarcinomas fromintratesticular grafts of pre- and postimplantation mouse embryos. Developmental Biology 21 364-382. (https://doi.org/10.1016/00121606(70)90130-2)

Sudheer S, Bhushan R, Fauler B, Lehrach H \& Adjaye J 2012 FGF inhibition directs BMP4-mediated differentiation of human embryonic stem cells to syncytiotrophoblast. Stem Cells and Development 21 2987-3000. (https://doi.org/10.1089/scd.2012.0099)

Sudheer S, Liu J, Marks M, Koch F, Anurin A, Scholze M, Senft AD, Wittler L, Macura K, Grote P et al. 2016 Different concentrations of FGF ligands, FGF2 or FGF8 determine distinct states of WNTinduced presomitic mesoderm. Stem Cells 34 1790-1800. (https://doi. org/10.1002/stem.2371)

Sui L, Bouwens L \& Mfopou JK 2013 Signaling pathways during maintenance and definitive endoderm differentiation of embryonic stem cells. International Journal of Developmental Biology 57 1-12. (https:// doi.org/10.1387/ijdb.120115ls)

Sukoyan MA, Vatolin SY, Golubitsa AN, Zhelezova AI, Semenova LA \& Serov OL 1993 Embryonic stem cells derived from morulae, inner cell mass, and blastocysts of mink: comparisons of their pluripotencies. Molecular Reproduction and Development 36 148-158. (https://doi. org/10.1002/mrd.1080360205)

Suzuki O, Matsuda J, Takano K, Yamam-oto Y, Asano T, Naiki M \& Kusanagi M 1999 Effect of genetic background onestablishment of mouse ESCs. Experimental Animals 48 213-216. (https://doi.org/10.1538/ expanim.48.213)

Tachibana M, Amato P, Sparman M, Gutierrez NM, Tippner-Hedges R, Ma H, Kang E, Fulati A, Lee HS, Sritanaudomchai H et al. 2013 Human embryonic stem cells derived by somatic cell nuclear transfer. Cell 153 1228-1238. (https://doi.org/10.1016/j.cell.2013.05.006)

Takahashi K \& Yamanaka S 2006 Induction of pluripotent stem cells from mouse embryonic and adult fibroblast cultures by defined factors. Cell 126 663-676. (https://doi.org/10.1016/j.cell.2006.07.024)

Takahashi K, Tanabe K, Ohnuki M, Narita M,Ichisaka T, Tomoda K \& Yamanaka S 2007 Induction of pluripotent stem cells from adult human fibroblasts by defined factors. Cell 131 861-872. (https://doi. org/10.1016/j.cell.2007.11.019)

Takashima Y, Guo G, Loos R, Nichols J, Ficz G, Krueger F, Oxley D, Santos F, Clarke J, Mansfield W et al. 2015 Resetting transcription factor control circuitry toward ground-state pluripotency in human. Cell $\mathbf{1 6 2}$ 452-453. (https://doi.org/10.1016/j.cell.2015.06.052)

Talluri TR, Kumar D, Glage S, Garrels W, Ivics Z, Debowski K, Behr R, Niemann H \& Kues WA 2015 Derivation and characterization of bovine induced pluripotent stem cells by transposon-mediated reprogramming. Cellular Reprogramming 17 131-140. (https://doi.org/10.1089/ cell.2014.0080)

Tapponnier Y, Afanassieff M, Aksoy I, Aubry M, Moulin A, Medjani L, Bouchereau W, Mayère C, Osteil P, Nurse-Francis J et al. 2017 Reprogramming of rabbit induced pluripotent stem cells toward epiblast and chimeric competency using Krüppel-like factors. Stem Cell Research 24 106-117. (https://doi.org/10.1016/j.scr.2017.09.001)

Telugu BPVL, Ezashi T \& Roberts RM 2010 Porcine induced pluripotent stem cells analogous to nave and primed embryonic stem cells of the 
mouse. International Journal of Developmental Biology 54 1703-1711. (https://doi.org/10.1387/ijdb.103200bt)

Tesar PJ 2005 Derivation of germ-line-competent embryonic stem cell lines from preblastocyst mouse embryos. PNAS 102 8239-8244. (https://doi. org/10.1073/pnas.0503231102)

Tesar PJ, Chenoweth JG, Brook FA, Davies TJ, Evans EP, Mack DL, Gardner RL \& Mckay RDG 2007 New cell lines from mouse epiblast share defining features with human embryonic stem cells. Nature $\mathbf{4 4 8}$ 196-199. (https://doi.org/10.1038/nature05972)

Theunissen TW, Powell BE, Wang H, Mitalipova M, Faddah DA, Reddy J, Fan ZP, Maetzel D, Ganz K, Shi L et al. 2014 Systematic identification of culture conditions for induction and maintenance of naive human pluripotency. Cell Stem Cell 15 471-487. (https://doi.org/10.1016/j. stem.2014.07.002)

Theunissen TW, Friedli M, He Y, Planet E, O'Neil RC, Markoulaki S, Pontis J, Wang H, louranova A, Imbeault M et al. 2016 Molecular criteria for defining the naive human pluripotent state. Cell Stem Cell 19 502-515. (https://doi.org/10.1016/j.stem.2016.06.011)

Thomson JA, Itskovitz-eldor J, Shapiro SS, Waknitz MA, Swiergiel JJ, Marshall VS \& Jones JM 1998 Embryonic stem cell lines derived from human blastocysts. Science 282 1145-1147. (https://doi.org/10.1126/ science.282.5391.1145)

Thomson M, Liu SJ, Zou LN, Smith Z, Meissner A \& Ramanathan S 2011 Pluripotency factors in embryonic stem cells regulate differentiation into germ layers. Cell 145 875-889. (https://doi.org/10.1016/j. cell.2011.05.017)

Tomioka I, Maeda T, Shimada H, Kawai K, Okada Y, Igarashi H, Oiwa R, Iwasaki T, Aoki M, Kimura T et al. 2010 Generating induced pluripotent stem cells from common marmoset (Callithrix jacchus) fetal liver cells using defined factors, including Lin28. Genes to Cells 15 959-969. (https://doi.org/10.1111/j.1365-2443.2010.01437.x)

Vaags AK, Rosic-Kablar S, Gartley CJ, Zheng YZ, Chesney A Villagómez DA, Kruth SA \& Hough MR 2009 Derivation and characterization of canine embryonic stem cell lines with in vitro and in vivo differentiation potential. Stem Cells 27 329-340. (https://doi. org/10.1634/stemcells.2008-0433)

Vallier L, Alexander M \& Pedersen RA 2005 Activin/Nodal and FGF pathways cooperate to maintain pluripotency of human embryonic stem cells. Journal of Cell Science 118 4495-4509. (https://doi.org/10.1242/ jcs.02553)

Wakayama S, Hikichi T, Suetsugu R, Sakaide Y, Bui HT, Mizutani E \& Wakayama T 2007 Efficient establishment of mouse embryonic stem cell lines from single blastomeres and polar bodies. Stem Cells 25 986-993. (https://doi.org/10.1634/stemcells.2006-0615)

Wang L, Schulz TC, Sherrer ES, Dauphin DS, Shin S, Nelson AM, Ware CB, Zhan M, Song CZ, Chen X et al. 2007 Self-renewal of human embryonic stem cells requires insulin-like growth factor-1 receptor and ERBB2 receptor signaling. Blood $1104111-4119$. (https://doi.org/10.1182/ blood-2007-03-082586)

Ware CB, Nelson AM, Mecham B, Hesson J, Zhou W, Jonlin EC, JimenezCaliani AJ, Deng X, Cavanaugh C, Cook S et al. 2014 Derivation of naive human embryonic stem cells. PNAS 111 4484-4489. (https://doi. org/10.1073/pnas.1319738111)

Warrier S, Van der Jeught M, Duggal G, Tilleman L, Sutherland E, Taelman J, Popovic M, Lierman S, Chuva De Sousa Lopes S, Van Soom A et al. 2017 Direct comparison of distinct naive pluripotent states in human embryonic stem cells. Nature Communications 8 1-10.

Weinberger L, Ayyash M, Novershtern N \& Hanna JH 2016 Dynamic stem cell states: naive to primed pluripotency in rodents and humans. Nature Reviews: Molecular Cell Biology 17 155-169. (https://doi.org/10.1038/ nrm.2015.28)

Wernig M, Meissner A, Foreman R, Brambrink T, Ku M, Hochedlinger $K$, Bernstein BE \& Jaenisch R 2007 In vitro reprogramming of fibroblasts into a pluripotent ES-cell-like state. Nature 448 318-324. (https://doi. org/10.1038/nature05944)

Williams RL, Hilton DJ, Pease S, Willson TA, Stewart CL, Gearing DP, Wagner EF, Metcalf D, Nicola NA \& Gough NM 1988 Myeloid leukaemia inhibitory factor maintains the developmental potential of embryonic stem cells. Nature 336 684-687. (https://doi.org/10.1038/336684a0)

Wu G \& Schöler HR 2016 Lineage segregation in the totipotent embryo. Current Topics in Developmental Biology 117 301-317. (https://doi. org/10.1016/bs.ctdb.2015.10.014)

Wu Y, Zhang Y, Mishra A, Tardif SD \& Hornsby PJ 2010 Generation of induced pluripotent stem cells from newborn marmoset skin fibroblasts. Stem Cell Research 4 180-188. (https://doi.org/10.1016/j. scr.2010.02.003)

Wu Y, Mishra A, Qiu Z, Farnsworth S, Tardif SD \& Hornsby PJ 2012 Nonhuman primate induced pluripotent stem cells in regenerative medicine. Stem Cells International 2012 767195. (https://doi. org/10.1155/2012/767195)

Wunderlich S, Kircher M, Vieth B, Haase A, Merkert S, Beier J, Göhring G, Glage S, Schambach A, Curnow EC et al. 2014 Primate iPS cells as tools for evolutionary analyses. Stem Cell Research 12 622-629. (https://doi. org/10.1016/j.scr.2014.02.001)

Xu RH, Chen X, Li DS, Li R, Addicks GC, Glennon C, Zwaka TP \& Thomson JA 2002 BMP4 initiates human embryonic stem cell differentiation to trophoblast. Nature Biotechnology 20 1261-1264. (https://doi.org/10.1038/nbt761)

Xu Y, Zhu X, Hahm HS, Wei W, Hao E, Hayek A \& Ding S 2010 Revealing a core signaling regulatory mechanism for pluripotent stem cell survival and self-renewal by small molecules. PNAS 107 8129-8134. (https://doi. org/10.1073/pnas.1002024107)

Yamanaka Y, Ralston A, Stephenson RO \& Rossant J 2006 Cell and molecular regulation of the mouse blastocyst. Developmental Dynamics 235 2301-2314. (https://doi.org/10.1002/dvdy.20844)

Ye S, Liu D \& Ying Q-L 2014 Signaling pathways in induced naïve pluripotency. Current Opinion in Cell Biology 49 1841-1850. (https:// doi.org/10.1016/j.gde.2014.08.002)

Ying QL, Nichols J, Chambers I \& Smith A 2003 BMP induction of Id proteins suppresses differentiationand sustains embryonic stem cell selfrenewal in collaboration with STAT3. Cellule 115 281-292. (https://doi. org/10.1016/S0092-8674(03)00847-X)

Ying QL, Wray J, Nichols J, Batlle-Morera L, Doble B, Woodgett J, Cohen P \& Smith A 2008 The ground state of embryonic stem cell self-renewal. Nature 453 519-523. (https://doi.org/10.1038/nature06968)

Yu J, Vodyanik MA, Smuga-Otto K, Antosiewicz-Bourget J, Frane JL, Tian S, Nie J, Jonsdottir GA, Ruotti V, Stewart R et al. 2007 Induced pluripotent stem cell lines derived from human somatic cells. Science 318 1917-1920. (https://doi.org/10.1126/science.1151526)

Zhang X, Cao H, Bai S, Huo W \& Ma Y 2017 Differentiation and characterization of rhesus monkey atrial and ventricular cardiomyocytes from induced pluripotent stem cells. Stem Cell Research 20 21-29. (https://doi.org/10.1016/j.scr.2017.02.002)

Zimmerlin L, Park TS, Huo JS, Verma K, Pather SR, Talbot CC, Agarwal J, Steppan D, Zhang YW, Considine M et al. 2016 Tankyrase inhibition promotes a stable human naïve pluripotent state with improved functionality. Development 143 4368-4380. (https://doi.org/10.1242/ dev.138982)

Received 13 February 2018

First decision 9 March 2018

Revised manuscript received 16 April 2019

Accepted 29 April 2019 